\title{
Influence of primary tillage on agrochemical indicators of soil fertility
}

\author{
Dmitry Dubovik*, Elena Dubovik, Alexander Morozov \\ Kursk Federal Agricultural Research Center, 70 b, Karl Marx st., Kursk, 305021, Russia
}

\begin{abstract}
The influence of primary tillage practices (plowing, subsurface tillage, surface tillage, direct sowing (No-till)) on the indicators of soil fertility of typical chernozem in Kursk Region on peas was studied. It was found that with the minimization of tillage humus content in the soil increased, especially in the upper 0-10 cm layer. Acidification of arable soil layer was noted when plowing was used. The content of mobile phosphorus, as well as the degree of its mobility, significantly increased with boardless tillage methods in comparison with moldboard plowing. The maximum amount of exchangeable potassium and the degree of its mobility were in case of direct sowing. The highest level of mineral nitrogen in the layer of $0-20 \mathrm{~cm}$ was formed in case of plowing, and its minimum level was formed in case of direct sowing. When tillage was minimized, the topsoil was differentiated by the content of mobile forms of copper, zinc and manganese. In a layer of 0-10 cm, combined tillage, surface tillage and direct sowing increased the content of mobile trace elements compared to a layer of $10-20 \mathrm{~cm}$. When plowing was used as a primary tillage method, the content of mobile copper, zinc and manganese was higher in the layer of $10-20 \mathrm{~cm}$.
\end{abstract}

\section{Introduction}

One of the main tasks of agricultural production is improving the efficiency of the use of material and natural resources taking into account the reproduction of soil fertility. This requires the development and implementation of innovative technologies for crop cultivation at various levels of intensity. Tillage is one of the agricultural practices that affect physical and chemical soil properties [1]. At present a fairly wide range of tillage practices is used in Russia from deep moldboard plowing to direct sowing $[2,3]$. When they are used, both positive and negative consequences are noted, especially when minimizing primary tillage.

The problem of changing agrochemical indicators of soil fertility during the transition to minimal tillage systems is particularly important. Thus, when soil cultivation is minimized, there is an increase in mineral nitrogen deficiency [4], a decrease in the amount of mobile phosphorus and potassium [5], and a change in the nitrogen and carbon regimes of the soil [6]. This should be taken into account when developing technologies for growing crops and, in particular, peas cultivation technologies.

The purpose of these studies is to determine the influence of primary tillage practices on the indicators of soil fertility under peas in Kursk Region.

\section{Materials and methods}

The research was carried out in the field stationary experiment of Kursk Federal Agricultural Research Center (Kursk Region, Kursk District, Cheryomushki settlement) in 2019-2020 in a four-field crop rotation. The crop rotation was deployed in the space with all four fields with the following alternation of crops: peaswinter wheat-soybean-barley.

The layout of the experiment included the following variants: moldboard plowing (20-22 cm deep); combined tillage (disking 8-10 cm + chisel 20-22 cm); surface tillage (disking) up to $8 \mathrm{~cm}$; direct sowing (No-till). The No-till variant was carried out without any tillage, using a direct sowing drill Don 114. Tillage practices have been applied systematically since 2015 for each variant.

The variants in the field experiment were placed systematically in one layer. The area of the sowing plot was $6000 \mathrm{~m}^{2}(60 \times 100)$, the tier was three-fold. The research was carried out in the second cycle of the crop rotation with Cadet variety peas. The soil of the experimental plot was represented by a typical deep heavy-loamy chernozem.

Agrochemical indicators of soil fertility were determined by the following methods: total humus by GOST 26213-91; alkaline hydrolyzable nitrogen by Cornfield method; mobile phosphorus and potassium by Chirikov method (GOST 26204-91); exchange calcium and magnesium by GOST 26487-85; $\mathrm{pH}_{\mathrm{KCl}}$ by GOST 26483-85; hydrolytic acidity by GOST 26212-91; nitrate nitrogen by GOST 26488-85; mobility degree of phosphorus and potassium by Guidelines for 
Determining the Degree of Mobility of Phosphorus and Potassium in Soils [7]. Statistical processing of the obtained data was carried out using Microsoft Excel and Statistica programs.

\section{Results and discussion}

The studied methods of primary tillage had an impact on the change in a number of indicators of soil fertility. Thus, the highest humus content on the average $5.17 \%$ in the soil layer of $0-20 \mathrm{~cm}$ was noted with direct sowing (Table 1). The amount of humus close to this variant was $5.14 \%$ in case of surface tillage. In the variants with plowing and combined tillage the humus content in the soil was lower compared to direct sowing by 0.34 and $0.36 \%$, respectively. At the same time, when plowing, combined and surface tillage were used, there was a tendency to accumulate humus in the upper $0-10 \mathrm{~cm}$ layer of the soil. The difference in the humus content between the $0-10 \mathrm{~cm}$ layer and the $10-20 \mathrm{~cm}$ layer was $0.09 \%$ for plowing, $0.05 \%$ for combined and surface tillage methods, but it was insignificant. In case of direct sowing the amount of humus in the $0-10 \mathrm{~cm}$ layer was $0.21 \%$ less than that in the $10-20 \mathrm{~cm}$ layer. A more significant difference between the soil layers in the direct sowing variant was obviously due to the large amount of unhumified plant residues in the upper layer as compared with other variants of primary tillage methods $(\mathrm{r}=-0.25)$.

The content of alkaline hydrolyzable nitrogen decreased with a decrease in the depth of tillage (Table 1). On the average, its minimum content in the soil was in the variant with surface tillage, i.e. $14.34 \mathrm{mg} / 100 \mathrm{~g}$.

Table 1. Content of humus and alkaline hydrolyzable nitrogen in typical chernozem

\begin{tabular}{|l|c|c|c|}
\hline $\begin{array}{c}\text { Primary tillage } \\
\text { practice }\end{array}$ & Depth (cm) & Humus (\%) & $\begin{array}{c}\text { N alk.- } \\
\text { hydrol. } \\
\text { (mg/100 g) }\end{array}$ \\
\hline \multirow{2}{*}{ Plowing } & $0-10$ & 4.87 & 15.43 \\
\cline { 2 - 4 } & $10-20$ & 4.78 & 15.58 \\
\hline \multirow{2}{*}{$\begin{array}{l}\text { Combined } \\
\text { tillage }\end{array}$} & $0-10$ & 4.83 & 15.14 \\
\cline { 2 - 4 } & $10-20$ & 4.78 & 15.36 \\
\hline \multirow{2}{*}{ Surface tillage } & $0-10$ & 5.16 & 14.12 \\
\cline { 2 - 4 } & $10-20$ & 5.11 & 14.56 \\
\hline \multirow{2}{*}{$\begin{array}{l}\text { Direct sowing } \\
\text { (No-till) }\end{array}$} & $0-10$ & 5.06 & 14.78 \\
\cline { 2 - 4 } & $10-20$ & 5.27 & 15.22 \\
\hline \multirow{2}{*}{ LSD05 } & tillage & 0.31 & 0.70 \\
\cline { 2 - 4 } & layer & 0.21 & 0.50 \\
\hline
\end{tabular}

The highest amount of alkaline hydrolyzable nitrogen in the soil was observed in case of plowing, i.e. 15.51 $\mathrm{mg} / 100 \mathrm{~g}$. At the same time, the difference between the soil layers of 0-10 and 10-20 cm was insignificant, but a tendency to accumulate alkaline hydrolyzable nitrogen in the lower layer of 10-20 cm was noted. The differences in the level of alkaline hydrolyzable nitrogen when different methods of primary tillage were used were due to the hydrothermal conditions that developed in the soil, which affected the rate of mineralization of organic matter and the release of available mineral nitrogen from it. A very high correlation was established between the content of alkaline hydrolyzable nitrogen in the soil and the reserves of productive moisture $(r=0.91)$.

The level of soil acidity varied significantly depending on a primary tillage practice (Table 2). No significant changes in soil $\mathrm{pH}$ were found between the soil layers. On the average, the most acidic reaction of the soil solution was detected in case of plowing, $\mathrm{pH}_{\mathrm{KCl}}$ was 5.2, and the least acidic one (5.6) in case of surface tillage.

The character of the change in the hydrolytic acidity of the soil was similar to the $\mathrm{pH}$ values, since there was an inverse direct relation between them $(r=-0.99)$.

The content of exchangeable calcium and magnesium differed insignificantly by the soil layers and the methods of primary tillage. A tendency to decrease calcium content with an increase in the acidity level of typical chernozem was noted, which was explained by an increase in its solubility in acidic soil $(r=0.67)$.

Table 2. Acid-base properties of the soil

\begin{tabular}{|l|c|c|c|c|c|}
\hline \multirow{2}{*}{$\begin{array}{c}\text { Primary } \\
\text { tillage } \\
\text { practice }\end{array}$} & \multirow{2}{*}{$\begin{array}{c}\text { Depth } \\
(\mathrm{cm})\end{array}$} & $\mathrm{pH}$ & $\mathrm{H}$ hy & \multicolumn{3}{|c|}{$\mathrm{me} / 100 \mathrm{~g}$} \\
\hline \multirow{2}{*}{ Plowing } & $0-10$ & 5.2 & 5.31 & 21.2 & 5.0 \\
\cline { 2 - 6 } & $10-20$ & 5.3 & 4.78 & 21.6 & 4.6 \\
\hline \multirow{2}{*}{$\begin{array}{c}\text { Combined } \\
\text { tillage }\end{array}$} & $0-10$ & 5.4 & 4.32 & 21.2 & 4.2 \\
\cline { 2 - 6 } & $10-20$ & 5.5 & 3.86 & 21.6 & 4.2 \\
\hline \multirow{2}{*}{ Surface tillage } & $0-10$ & 5.6 & 3.54 & 22.0 & 4.2 \\
\cline { 2 - 6 } & $10-20$ & 5.6 & 3.50 & 22.0 & 5.0 \\
\hline \multirow{2}{*}{$\begin{array}{l}\text { Direct sowing } \\
\text { (No-till) }\end{array}$} & $0-10$ & 5.5 & 3.95 & 21.2 & 4.6 \\
\cline { 2 - 6 } & $10-20$ & 5.5 & 3.93 & 21.6 & 4.6 \\
\hline \multirow{2}{*}{ LSD05 } & tillage & 0.13 & 0.61 & 0.45 & 1.13 \\
\cline { 2 - 6 } & layer & 0.10 & 0.43 & 0.32 & 0.80 \\
\hline
\end{tabular}

When studying the phosphorus-potassium regime of typical chernozem, the following regularities depending on the practices of primary tillage used were established.

Both in the $0-10 \mathrm{~cm}$ soil layer and in the $10-20 \mathrm{~cm}$ layer, in the variant with moldboard plowing, the lowest content of mobile forms of phosphorus was observed as compared with the other studied variants (16.6 and 17.0 $\mathrm{mg} / 100 \mathrm{~g}$ ) (Table 3). When switching to non-moldboard tillage methods, the amount of mobile phosphorus increased by $2.3-2.9 \mathrm{mg} / 100 \mathrm{~g}$ on the average in the $0-20$ $\mathrm{cm}$ layer. By the level of accumulation of mobile phosphorus, the variants with minimization of primary tillage did not differ significantly (by 0.1-0.6 mg/100 g). There were no significant differences in the content of mobile phosphorus in the soil layers. A tendency was only noted to a slight increase in the amount of phosphorus in the $0-10 \mathrm{~cm}$ layer in the variants with 
minimal tillage practices and a decrease in this layer in case of plowing.

The character of the change in the degree of phosphorus mobility copied the patterns in its distribution by the experimental variants, which was due to a noticeable relationship between those indicators $(r=0.60)$. Thus, the lowest degree of phosphorus mobility was observed in the variant with plowing $(0.232 \mathrm{mg} / \mathrm{l})$, and the highest degree in that with direct sowing $(0.253$ $\mathrm{mg} / \mathrm{l})$.

The highest content of exchangeable potassium in the soil was in case of direct sowing (on the average, 14.1 $\mathrm{mg} / 100 \mathrm{~g}$ ) (Table 3). In comparison with direct sowing, the amount of potassium, on the average, in the layer of $0-20 \mathrm{~cm}$ was reduced in the variants with plowing by 1.4 $\mathrm{mg} / 100 \mathrm{~g}$, combined tillage by $2.3 \mathrm{mg} / 100 \mathrm{~g}$, surface tillage by $2.5 \mathrm{mg} / 100 \mathrm{~g}$.

By the soil layers, an increase was observed in the content of exchangeable potassium in the $0-10 \mathrm{~cm}$ layer by $1.1 \mathrm{mg} / 100 \mathrm{~g}$. When the other methods of primary tillage were used, no significant differences in the content of potassium in the soil layers were revealed. It can be noted that as the depth of tillage decreased the character of the content of exchangeable potassium varied from the accumulation in the lower layers of 10$20 \mathrm{~cm}$ (plowing and combined tillage) to the concentration in the upper layer (direct sowing).

Table 3. Phosphorus-potassium regime of typical chernozem

\begin{tabular}{|l|c|c|c|c|c|}
\hline \multirow{2}{*}{$\begin{array}{c}\text { Primary } \\
\text { tillage } \\
\text { practice }\end{array}$} & \multirow{2}{*}{$\begin{array}{c}\text { Depth } \\
(\mathrm{cm})\end{array}$} & \multirow{2}{*}{$\mathrm{P}_{2} \mathrm{O}_{5}$} & \multirow{2}{*}{$\mathrm{K}_{2} \mathrm{O}$} & \multicolumn{2}{|c|}{$\begin{array}{c}\text { Degree of } \\
\text { mobility }\end{array}$} \\
\cline { 3 - 6 } & & \multicolumn{2}{|c|}{$\mathrm{mg} / 100 \mathrm{~g}$} & \multicolumn{2}{|c|}{$\mathrm{mg} / 1$} \\
\hline \multirow{2}{*}{ Plowing } & $0-10$ & 16.6 & 12.3 & 0.231 & 3.8 \\
\cline { 2 - 6 } & $10-20$ & 17.0 & 13.0 & 0.233 & 4.6 \\
\hline $\begin{array}{l}\text { Combined } \\
\text { tillage }\end{array}$ & $0-10$ & 19.2 & 11.6 & 0.260 & 3.5 \\
\cline { 2 - 6 } $\begin{array}{l}\text { Surface } \\
\text { tillage }\end{array}$ & $10-20$ & 19.0 & 12.0 & 0.241 & 3.8 \\
\hline \multirow{2}{*}{$\begin{array}{l}\text { Direct } \\
\text { sowing } \\
\text { (No-till) }\end{array}$} & $10-20$ & 18.6 & 11.6 & 0.258 & 3.3 \\
\hline \multirow{2}{*}{$\mathrm{LSD}_{05}$} & $0-10$ & 19.2 & 14.6 & 0.221 & 3.3 \\
\cline { 2 - 6 } & $10-20$ & 19.2 & 13.5 & 0.256 & 5.0 \\
\cline { 2 - 6 } & tillage & 2.17 & 1.77 & 0.07 & 4.6 \\
\hline
\end{tabular}

The degree of potassium mobility resembled the features of the distribution of its exchangeable form, since these indicators were in a very high degree of dependence $(\mathrm{r}=0.96)$. The highest degree of potassium mobility of $4.8 \mathrm{~g} / \mathrm{l}$ was observed in case of direct sowing, and the lowest degree of $3.3 \mathrm{~g} / \mathrm{l}$ in case of direct sowing. The content of nitrate nitrogen in the soil in the variant with plowing was higher by 0.64 and $0.63 \mathrm{mg} / 100 \mathrm{~g}$ (in the layer of 0-10 and $10-20 \mathrm{~cm}$, respectively) than in that with combined tillage, by 0.50 and $0.37 \mathrm{mg} / \mathrm{kg}$ than with the surface tillage, and by 0.61 and $0.69 \mathrm{mg} / 100 \mathrm{~g}$ than with the direct sowing (Table 4). At the same time, in the layer of $0-10 \mathrm{~cm}$ the amount of nitrate nitrogen was higher by $0.07-0.28 \mathrm{mg} / 100 \mathrm{~g}$ than that in the layer 10 $20 \mathrm{~cm}$, regardless of the tillage method.

The highest content of ammonium nitrogen was also in the soil under plowing -0.48 and $0.58 \mathrm{mg} / 100 \mathrm{~g}$ in the layers $0-10$ and $10-20 \mathrm{~cm}$. The minimum content of ammonium nitrogen was observed in case of surface tillage $0.28 \mathrm{mg} / 100 \mathrm{~g}$ and direct sowing $0.31 \mathrm{mg} / 100 \mathrm{~g}$. There were no significant differences in the content of ammonium nitrogen between the soil layers, but the accumulation of $\mathrm{N}^{-\mathrm{NH}_{4}}$ in the $10-20 \mathrm{~cm}$ layer in case of plowing $(+0.10 \mathrm{mg} / 100 \mathrm{~g})$ can be noted.

In general, it can be noted that the accumulation of mineral nitrogen in the soil $\left(\mathrm{N}-\mathrm{NO}_{3}+\mathrm{N}-\mathrm{NH}_{4}\right)$ occurred most intensively when plowing was used as primary tillage practice $(1.92-2.17 \mathrm{mg} / 100 \mathrm{~g})$. Minimization of tillage led to a decrease in the amount of mineral nitrogen in the soil, and the lowest content (1.10-1.24 $\mathrm{mg} / 100 \mathrm{~g}$ ) was observed in case of direct sowing.

Table 4. Mineral nitrogen content in the soil

\begin{tabular}{|c|c|c|c|c|}
\hline \multirow{2}{*}{$\begin{array}{l}\text { Primary } \\
\text { tillage } \\
\text { practice }\end{array}$} & \multirow{2}{*}{ Depth (cm) } & $\mathrm{N}-\mathrm{NO}_{3}$ & $\mathrm{~N}-\mathrm{NH}_{4}$ & $\Sigma$ \\
\hline & & \multicolumn{3}{|c|}{$\mathrm{mg} / 100 \mathrm{~g}$} \\
\hline \multirow{2}{*}{ Plowing } & $0-10$ & 1.44 & 0.48 & 1.92 \\
\hline & $10-20$ & 1.59 & 0.58 & 2.17 \\
\hline \multirow{2}{*}{$\begin{array}{l}\text { Combined } \\
\text { tillage }\end{array}$} & $0-10$ & 0.80 & 0.42 & 1.22 \\
\hline & $10-20$ & 0.96 & 0.37 & 1.33 \\
\hline \multirow{2}{*}{$\begin{array}{l}\text { Surface } \\
\text { tillage }\end{array}$} & $0-10$ & 0.94 & 0.29 & 1.23 \\
\hline & $10-20$ & 1.22 & 0.27 & 1.49 \\
\hline \multirow{2}{*}{$\begin{array}{l}\text { Direct sowing } \\
\text { (No-till) }\end{array}$} & $0-10$ & 0.83 & 0.27 & 1.10 \\
\hline & $10-20$ & 0.90 & 0.34 & 1.24 \\
\hline \multirow{2}{*}{$\mathrm{LSD}_{05}$} & tillage & 0.20 & 0.16 & 0.17 \\
\hline & layer & 0.14 & 0.11 & 0.12 \\
\hline
\end{tabular}

In general, it can be noted that the accumulation of mineral nitrogen in the soil $\left(\mathrm{N}^{-\mathrm{NO}_{3}}+\mathrm{N}-\mathrm{NH}_{4}\right)$ occurred most intensively when plowing was used as primary tillage practice $(1.92-2.17 \mathrm{mg} / 100 \mathrm{~g})$. Minimization of tillage led to a decrease in the amount of mineral nitrogen in the soil, and the lowest content (1.10-1.24 $\mathrm{mg} / 100 \mathrm{~g}$ ) was observed in case of direct sowing. Obviously, that was due to the fact that in case of minimal tillage and especially direct sowing, stubble and mulch of plant residues left on the surface formed microclimate that helped to slow down biomass decomposition and reduce the processes of ammonification. As a result, nitrification, i.e. the oxidation of ammonia to nitrates, also decreased. Plowing stimulated the decomposition of plant residues, as a result of which the mobilization of available forms of nitrogen increased [8].

Among the indicators of soil fertility, the content of mobile forms of trace elements occupies an important place. Soil is the main source of trace elements for plants. Despite their containing in the soil in small quantities, trace elements are indispensable for the normal functioning of agricultural plants, so it is necessary to know the level of their content in the soil for timely replenishment of their deficit. Among the many trace elements, copper, zinc and manganese play an important role. 
Table 5. Content of trace elements in the soil depending on primary tillage methods

\begin{tabular}{|l|c|c|c|c|}
\hline \multirow{2}{*}{$\begin{array}{c}\text { Primary } \\
\text { tillage } \\
\text { practice }\end{array}$} & \multirow{2}{*}{ Depth $(\mathrm{cm})$} & \multicolumn{3}{|c|}{$\begin{array}{c}\text { Content of trace elements, } \\
\mathrm{mg} / \mathrm{kg}\end{array}$} \\
\cline { 2 - 5 } & & $\mathrm{Cu}$ & $\mathrm{Zn}$ & $\mathrm{Mn}$ \\
\hline \multirow{3}{*}{ Plowing } & $0-10$ & 0.04 & 2.1 & 15.6 \\
\cline { 2 - 5 } & $10-20$ & 0.05 & 2.5 & 16.5 \\
\hline \multirow{2}{*}{$\begin{array}{l}\text { Combined } \\
\text { tillage }\end{array}$} & $0-10$ & 0.03 & 2.5 & 20.0 \\
\cline { 2 - 5 } $\begin{array}{l}\text { Surface } \\
\text { tillage }\end{array}$ & $10-20$ & 0.03 & 1.8 & 15.2 \\
\hline \multirow{2}{*}{$\begin{array}{l}\text { Direct sowing } \\
\text { (No-till) }\end{array}$} & $0-10$ & 0.05 & 1.8 & 17.8 \\
\cline { 2 - 5 } & $10-20$ & 0.04 & 1.4 & 17.0 \\
\hline \multirow{2}{*}{ LSD05 } & $10-20$ & 0.03 & 2.0 & 12.0 \\
\cline { 2 - 5 } & tillage & 0.03 & 0.5 & 2.4 \\
\cline { 2 - 5 } & layer & 0.02 & 0.3 & 1.4 \\
\hline
\end{tabular}

Copper is an essential element for the normal functioning of plants. With a lack of copper, the activity of enzymes involved in the processes of photosynthesis and respiration decreases. Copper deficiency affects the formation of generative organs. Zinc has important functions in the metabolism of carbohydrates, proteins, and phosphates in plants. With a lack of this element in plants, photosynthesis is disrupted, the rate of protein synthesis decreases, the growth of shoots is slowed down, and the deformation of leaves and fruits is observed. Manganese participates in the oxygen-forming system of photosynthesis. Manganese also plays an important role in catalytic reactions as an activator. With a deficiency of manganese in plants, chlorosis is observed, plant growth is delayed, and frost resistance decreases.

As a result of the studies, it was found that the content of mobile copper in the soil did not differ significantly depending on the practices of primary tillage (Table 5). It can be noted that direct sowing being used, the amount of mobile copper in the soil layer of 0$10 \mathrm{~cm}$ was 2.7 times higher than that in the layer of 10$20 \mathrm{~cm}$. With other tillage methods studied, there is no differentiation between the soil layers. In general, the content of mobile copper in the soil can be characterized as low [9].

The content of mobile zinc in the soil varied depending on the tillage method used and the soil layer. Thus, in case of plowing, there was a tendency to reduce the zinc content in the upper $0-10 \mathrm{~cm}$ layer and increase it in the $10-20 \mathrm{~cm}$ layer. When minimized tillage was used, on the contrary, there was an accumulation of zinc in the layer of $0-10 \mathrm{~cm}$, and its decrease in the layer of $10-20 \mathrm{~cm}$. This was especially noticeable in case of direct sowing, where the difference between the layers, in terms of zinc content, was $1.0 \mathrm{mg} / \mathrm{kg}$ of soil.

The content of mobile manganese in the soil varied depending on the tillage method. Thus, on the average, minimum level of mobile manganese was observed in direct sowing $(13.3 \mathrm{mg} / \mathrm{kg})$, and maximum level in combined $(17.6 \mathrm{mg} / \mathrm{kg})$ and surface $(17.4 \mathrm{mg} / \mathrm{kg})$ tillage. At the same time, minimized tillage contributed to the differentiation of the arable layer by the level of manganese content. Thus, in a layer of $0-10 \mathrm{~cm}$, there was an increase in the amount of mobile manganese when combined tillage was used by $4.8 \mathrm{mg} / \mathrm{kg}$, surface tillage by $0.8 \mathrm{mg} / \mathrm{kg}$, direct sowing by $1.5 \mathrm{mg} / \mathrm{kg}$, as compared with a layer of $10-20 \mathrm{~cm}$. In case of plowing, the manganese content in the $0-10 \mathrm{~cm}$ layer was by 0.9 $\mathrm{mg} / \mathrm{kg}$ lower than that in the $10-20 \mathrm{~cm}$ layer.

When tillage was minimized, the topsoil was differentiated by the content of mobile forms of copper, zinc and manganese. In a layer of 0-10 cm, combined tillage, surface tillage and direct sowing increased the content of mobile trace elements compared to a layer of $10-20 \mathrm{~cm}$. When plowing was used as a primary tillage method, the content of mobile copper, zinc and manganese was higher in the layer of $10-20 \mathrm{~cm}$.

\section{Conclusion}

Thus, it can be concluded that with tillage minimization the humus content in the soil increases with a tendency to be accumulated in the upper $0-10 \mathrm{~cm}$ layer. When plowing is used as a primary tillage practice, acidification of the topsoil layer is noted. The content of mobile phosphorus, as well as the degree of its mobility, significantly increases when non-moldboard tillage practices are used in comparison with moldboard plowing. The amount of exchangeable potassium and the degree of its mobility reach their maximum when direct sowing are used. The highest level of mineral nitrogen in a layer of $0-20 \mathrm{~cm}$ is formed with plowing, and the minimum level is formed with direct sowing.

\section{References}

1. V.I. Kiryushin, Zemled. 7, 3 (2013)

2. V.V. Kulintsev, V.K. Dridiger, Achievem. of Sci. and Techn. of AICis, 4, 16 (2014)

3. T.R.Jr. Aguiar, K. Rasera, L. Parron, et al. Agric. Water Manag. 149, 74 (2014)

4. A.A. Zavalin, V.K. Dridiger, V.P. Belobrov, S.A.Yudin, Eur. Soil Sci., 12, 1506 (2018)

5. N.A. Korotkikh, N.G. Vlasenko, Plodorod., 3, 23 (2015)

6. S.S. Malhi, M. Nyborg, T. Goddard, D. Puurveen, Nutr. Cycl. Agroecosyst. 90, 227 (2011)

7. V.G. Mineev, V.G. Sychev, O.A. Amelianchik et al. Laboratory Manual on Agrochemistry (MSU Russian, 2001)

8. A.A. Zavalin, O.A. Sokolov, N.Ya. Shmyreva Nitrogen in the Agrosystem on Chernozem Soils (RAS, 2018)

9. A. Kabata-Pendias, Trace Elements in Soils and Plants (Crc Press, 2010) 